\title{
REPRESENTATIONS ABOUT SUICIDE OF WOMEN WITH HISTORY OF DOMESTIC VIOLENCE AND SUICIDE ATTEMPT ${ }^{1}$
}

\author{
Cintia Mesquita Correia ${ }^{2}$, Nadirlene Pereira Gomes, ${ }^{3}$, Telmara Menezes Couto ${ }^{4}$, Adriana Diniz Rodrigues ${ }^{5}$, \\ Alacoque Lorenzini Erdmann ${ }^{6}$, Normélia Maria Freire Diniz
}

${ }^{1}$ Extract from the dissertation - Vivência de violência doméstica em mulheres que tentaram suicídio, submitted to the Graduate Program in Nursing of the Federal University of Bahia (UFBA), in 2011.

${ }^{2}$ Master in Nursing. Assistant Professor at the Public Health and Medical School of Bahia. Bahia, Brazil. E-mail: cintia.mes@ hotmail.com

${ }^{3}$ Ph.D. in Nursing. Adjunct Professor at the Nursing School of UFBA. Bahia, Brazil. E-mail: nadirlenegomes@hotmail.com

${ }^{4}$ Ph.D. in Nursing. Adjunct Professor at the Nursing School of UFBA. Bahia, Brazil. E-mail: telmaracouto@gmail.com

${ }^{5}$ Doctoral student at the Graduate Program in Nursing of UFBA. Nurse at the Obstetrical and Surgical Center of the Maternity Hospital Prof. José Maria Magalhães Netto. Bahia, Brazil. E-mail: a.dini@ig.com.br

${ }^{6}$ Ph.D. in Nursing Philosophy. Full Professor at the Nursing Department of the Federal University of Santa Catarina. 1A Scholar of CNPq. Santa Catarina, Brazil. E-mail: alacoque@newsite.com.br

7 Ph.D. in Nursing. Associate Professor at the Nursing School of UFBA. Bahia, Brazil. E-mail: normeliadiniz@gmail.com

\begin{abstract}
Suicide attempt is characterized by complex and multifaceted phenomena with significance on global public health. The aim of this study was to grasp the structure of social representations of suicide of women with history of domestic violence and suicide attempt. The study was developed with a qualitative approach, based on the Theory of Social Representations. There were 30 women that responded the Free Word Association Test, all of them with history of domestic violence and suicide attempt by poisoning. Data were processed through the EVOC software and the results were grouped into three categories: core elements, intermediate elements and peripheral elements. The representation of women about suicide is related to life histories characterized by rejection and lack of love, which leads to disease, especially because of depression. The feeling of powerlessness in face of the need for change and release produce emotional problems that culminate in the decision of committing suicide.
\end{abstract}

DESCRIPTORS: Domestic violence. Suicide. Attempted suicide. Nursing.

\section{REPRESENTAÇÕES SOBRE O SUICÍDIO PARA MULHERES COM HISTÓRIA DE VIOLÊNCIA DOMÉSTICA E TENTATIVA DO MESMO}

RESUMO: A tentativa de suicídio caracteriza-se por fenômenos complexos e multifacetados, com destaque na saúde pública mundial. O estudo teve como objetivo apreender a estrutura das representações sociais sobre o suicídio para mulheres com história de violência doméstica e tentativa do mesmo. Abordagem qualitativa, fundamentada na Teoria das Representações Sociais. Participaram do Teste de Associação Livre de Palavras 30 mulheres com história de violência doméstica e tentativa de suicídio por envenenamento. Os dados obtidos foram processados por meio do software EVOC e os resultados foram agrupados em três categorias: elementos do núcleo central, elementos intermediários e elementos periféricos. A representação das mulheres sobre o suicídio encontra-se ancorada em histórias de vida permeada pela rejeição e desamor, que leva à doença, sobretudo pela depressão. O sentimento de impotência diante da necessidade de mudança e libertação desencadeia problemas de âmbito emocional que culminam na decisão de interromper a própria vida.

DESCRITORES: Violência doméstica. Suicídio. Tentativa de suicídio. Enfermagem.

\section{REPRESENTACIONES SOBRE SUICIDIO DE MUJERES CON HISTORIA DE VIOLENCIA DOMESTICA E INTENTO DE SUICIDIO}

\begin{abstract}
RESUMEN: El intento de suicidio está caracterizado por fenómenos complejos y multifactoriales de relevancia para la salud pública mundial. Este estudio tuvo como objetivo comprender la estructura de las representaciones sociales de suicidio en las mujeres con un historial de violencia doméstica y que intentaron suicidio. Se trata de un estudio con enfoque cualitativo basado en la Teoría de las Representaciones Sociales. Se realizó el Test de Asociación Libre de Palabras a 30 mujeres con historia de violencia doméstica y tentativa de suicidio por envenenamiento. Los datos fueron procesados a través del software EVOC y los resultados agrupados en tres categorías: elementos del núcleo central, elementos intermediarios y elementos periféricos. La representación de las mujeres sobre el suicidio se basa en las historias de vida caracterizadas por el rechazo y la falta de amor, lo que lleva a la enfermedad, especialmente por la depresión. El sentimiento de impotencia frente a la necesidad de cambio y liberación desencadena problemas emocionales que terminan en la decisión de poner fin a la propia vida.
\end{abstract}

DESCRIPTORES: Violencia doméstica. Suicidio. Intento de suicídio. Enfermería. 


\section{INTRODUCTION}

Suicide and suicide attempt stand out as serious public health issues that directly impact morbi-mortality profiles. In Brazil, data from the Mortality Information System (MIS) reveal an ever-increasing number of suicide reports. In $1999,6,530$ deaths were reported, corresponding to nearly 18 deaths a day. In 2009, reports showed 9,374 deaths as a result of suicide, that is, over 25 deaths per day. ${ }^{1}$ Information provided by the Toxicological Center of the State of Bahia presents the highest numbers of suicide attempts by women. The most common methods are the use of medicines, rat poison and household products. ${ }^{2}$

The magnitude and the complexity of the suicide phenomenon have been generating countless studies in all societies worldwide. Several theories address the issue in different ways. Common sense points out that the suicide is, in its core essence, a behavioral deviation: religions in general condemn suicide; the medical practice deems it to be the result of a disease; and the psychology and psychoanalysis field most often consider suicide as the aftermath of long years of pain resulting from a variety of hardships in life.

The iconic book, "The Suicide", published in the dawn of the $19^{\text {th }}$ century, sought to point out that the causes of self-termination of life are socially, and not individually, built. The study shows that "the causes of this type of death are much more likely to be externally, rather than internally, located and it only affects individuals when they decide to cross the borderline of its sphere of action". 3:13 Unfortunate experiences in life that hinder a healthy emotional development, thus elevating the tension level, resulting in an overload of stressors and leading to a suicidal behavior, can be identified among the risk factors of suicide. ${ }^{4}$

Research on suicide and suicide attempts in women shows that violent environment are one of the reasons that trigger such radical act. These studies highlight that interpersonal losses, relationship difficulties, as well as physical, verbal and sexual violence histories constitute the major causes of such attempts. ${ }^{5-6}$

As for domestic violence, the traditional view of the family as a sacred sanctuary, mothercell and foundation of the social edifice acts as a determining factor toward generating a protection barrier that makes it difficult for the home-based violence to be perceived. ${ }^{5}$
Hence, as this private problem usually tends to go unnoticed, health professionals should be more aware of the fact that violence at large traumatizes, incapacitates, humiliates, frustrates, alters behaviors and leaves negative outcomes. Aiming at offering subsidies to the recognition of domestic violence as being damaging to the women's health status, with serious mental health implications that may lead to suicide attempts, the present study seeks to apprehend the framework of the social representations of suicide and suicide attempt in women with histories of domestic violence.

\section{METHODOLOGY}

This exploratory, descriptive study with a qualitative approach is grounded on the Theory of Social Representations. Social Representations (SR) consist in an organized set of information, attitudes and beliefs that an individual or group of individuals elaborate on a given subject, thus creating a subjective and social perception of reality. ${ }^{7}$ The theory is employed by several studies in the nursing field, thus allowing for an insight of how complex human phenomena are and contributing to enlighten the world views of the subjects inserted into a social context, the way they act and make decisions. In this perspective, it is crucial to understand the complexity of the decision for the suicide by women undergoing domestic violence.

Structured in a two-fold internal system - the core group and the peripheral system - the representations have a complementary pattern. The peripheral system is more flexible and protects the core group, allowing for the blending of distinct information and social practices, and enabling the transformation of unknown aspects into familiar issues. $^{8}$

The participants in the study were adult women cared for at the Suicide Prevention Study Center (SPSC), a department linked to the AntiPoison Information Center (APIC) located next to a general reference hospital for exogenous intoxications in the city of Salvador, state of Bahia, Brazil. These women had a history of domestic violence and used poison to commit suicide. The SPSC provides psychological, psychiatric and occupational therapy care for people who have attempted suicide by the use of poison.

The research took into account the criteria of the participants' employment length of time. As such, the universe of the study was restricted to the number of adult women who were registered 
in and active at the SPSC, total of 50 women. Among these, 30 women were deemed to be in emotional and psychic conditions of taking part in the study. All of them accepted to collaborate with the research.

The study complied with the ethical aspects provided by resolution 196/96 of the National Health Council, which guides research practices with human beings. The project was approved by the Research Ethics Committee of the Ana Neri Hospital under protocol number 50/2010, thus triggering the data collection process.

The women were approached at the Psychology Service responsible for the SPSC. At the first contact, the women were informed on the objective, relevance of the research and their right to decide both to participate and to quit at any time, with no harm at all to their treatment process at the SPSC. The women were also informed on the inexistence of any material or financial compensation and the full secrecy of any disclosed information. In addition, they were advised that the results of the research would be shown in events and published in indexed magazines, and that they would have to sign a Free and Informed Consent Form, containing the ethical issues previously mentioned, in case they decided to take part in the study.

Data were collected between June and December of 2010, by means of the Free Words Association Test (FWAT) and by interviews. The FWAT was employed to apprehend the structure of the representations of women with histories of domestic violence and suicide attempt. In the next step, women were interviewed in order to both comprehend their life contexts and ground and sustain the elements comprised in the social representations.

The FWAT is a technique used to collect elements that compose a given representation, as it uses verbal and non-verbal inducing stimuli toward provoking implicit or latent responses from the subjects to be assessed. This technique has been applied since the 1980's in a number of social representation works, thus demonstrating its validity. ${ }^{9}$

The test was performed with all of the 30 subjects in the study. The test was comprised of an open question - "which words come to your mind when I say the word 'suicide'?" - that allowed for a natural flow of free association of words. The women were asked to come up with five words. The words were, then, hierarchically organized according to the order of relevance assigned by the subjects. Then, all subjects numbered the words by order of relevance and chose two words that would most adequately define the term "suicide", justifying them afterwards.

The data produced by the FWAT were processed by the EVOC software, which classified the words by the combined analysis of the average order in which they were called forth and the average frequency of the words, that is, the number of times the word was mentioned. We could then identify the framework of the social representation of suicide by women with histories of domestic violence and suicide attempt by pointing out elements in the core group and the peripheral system by means of the four-fold diagram.

Among the 30 subjects who participated in the FWAT, ten were submitted to an in-depth interview, aiming to corroborate and reinforce the evidences obtained by the FWAT. This interview technique enriches the investigative process, as it enables the free speech of the interviewee, who, in this case, is not manipulated, allowing the researcher to find out spontaneous speech trends. ${ }^{10}$ The information produced by the research was organized under the Bardin's thematic analysis. After the exhaustive reading of the information, a series of identified messages could be grouped into similar categories; such categories were later related to the aspects that comprised the elements observed in the four-fold diagram. Data analysis was based on theoretical studies in the mental health field.

The interviews took place in reserved sites, in order to protect the privacy of the women and cause them to be more comfortable while talking about their lives. The average time of the interviews was 60 minutes. In order to ensure the women's anonymity, they were given fictitious names.

\section{RESULTS AND DISCUSSION}

The analysis of the corpus comprised of the 30 women identified 150 words in response to the inducing stimulus "suicide"; the analysis also displayed an average of 3 mention orders (AMO $=$ average mention orders) in a scale ranging from 1 through 5 . As for the frequency the words were mentioned, the cut-off point was lower than 3, and all terms with frequencies of 1 and 2 (9.33\%) were suppressed. Thus, the amount of mentioned terms reached $90.67 \%$. Following the suppression 
of the low frequency terms, the average frequency of mentions (132/17) was calculated, resulting in an approximate cut-off point of $\geq 8.0$.

From the 150 mentioned words, 31 were different, thus denoting the low dispersion of the terms around the representation of the researched issue. In other words, it pointed to the fact that the majority of women with domestic violence history and suicide attempt had a similar representation about the term "suicide". The combined analysis of data resulted in the four-fold diagram that follows (Figure 1).

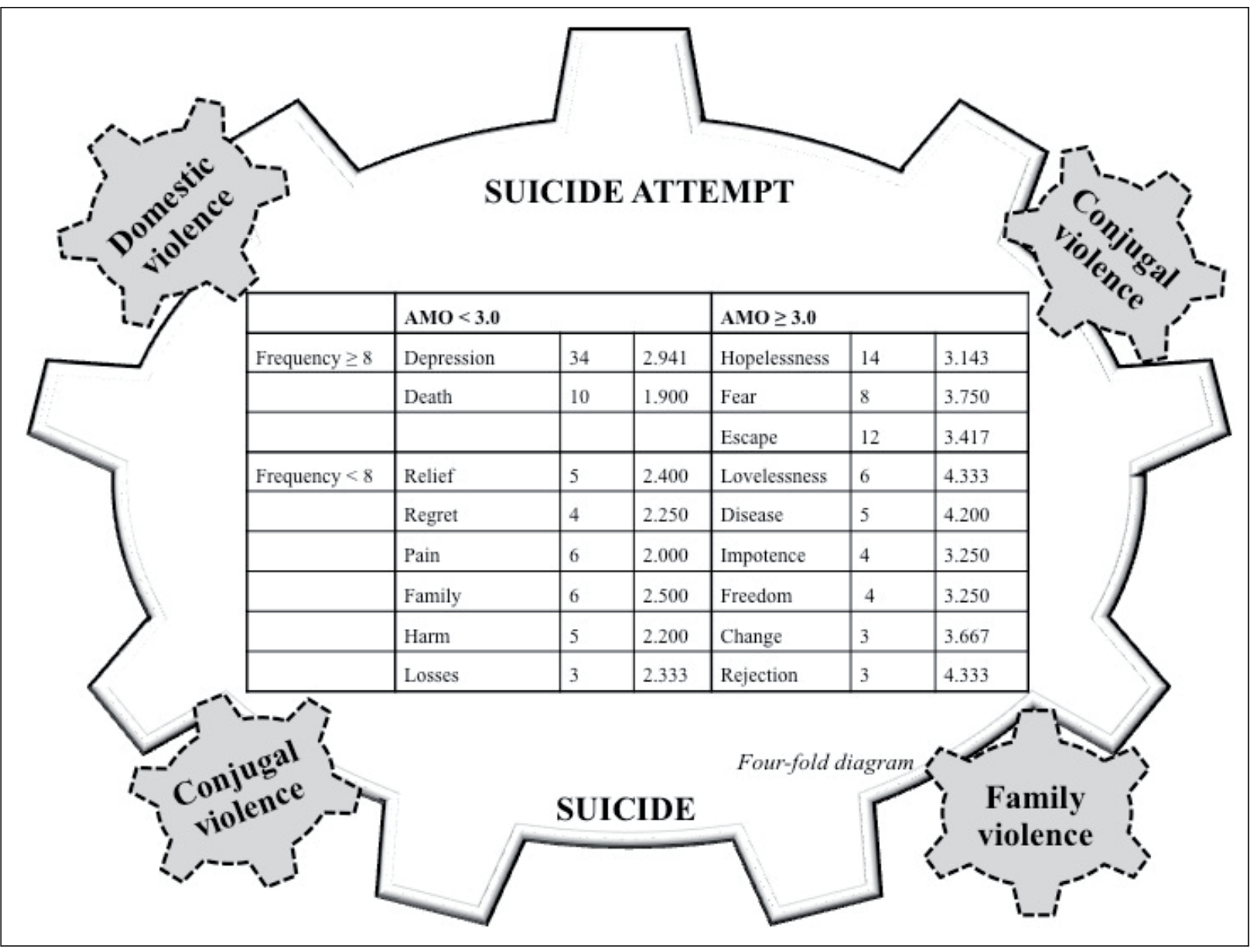

Figure 1 - Social representation of suicide by women with domestic violence history and suicide attempt. Salvador-BA, 2011

The layout of the four-fold diagram corresponds to four quadrants with four sets of terms each. The most stable and consensual terms among the subjects of the research constitute the core group of the SR and can be located at the higher left of the quadrant. The higher right quadrant and the lower left quadrant show the intermediary elements that tend to get closer to either the core group or the peripheral elements. The words located at the lower right quadrant correspond to the peripheral elements of the representation. ${ }^{11-12}$ In this perspective, the data were grouped in three categories: core group elements, intermediary elements, and peripheral elements.

\section{Core group elements}

The words gathered at the lower left quadrant showed a higher frequency and were prioritized in the word mentioning process, hence comprising the core group of the social representation about suicide among the women. Besides characterizing the most consensual and stable part of the representation, these elements were found to be less sensitive to changes as a result of either the external framework or the daily practices of the subjects. ${ }^{13}$

"Depression" and "death" are elements that integrate the core group of the social representation about suicide. The terms were deemed 
to be the most relevant by the women, thus displaying the real meaning of their representation of suicide.

As it may be observed, out of the 150 mentions, the terms "depression" and "death" were mentioned 44 times (29.3\%). For 13 (43.3\%) women, the mentioned words express the representation of suicide and are displayed as the first and most important elements.

The term "depression" was mentioned 34 times $(22.7 \%)$ and 14 women deemed it to be the $1^{\text {st }}$ and $2^{\text {nd }}$ most relevant elements. In the interviews, women directly connect the term "depression" with the term "suicide": depression showed up, first of all, then the suicide attempt [...] (S2).

According to the World Report on Mental Health, the general prevalence of mental and behavioral disorders seem not to show any difference between men and women, although anxiety and depression disorders are more common in women. ${ }^{14}$ One of the favorable explanations to this fact is related to the domestic violence these women undergo, as these traumatic occurrences are capable of unleashing psychic alterations that may generate depression disorders: the depression started out [...] when my husband wronged me in quite a cruel way [...] I underwent violence [...] (S3).

The term "death" was mentioned 10 times $(6.6 \%)$ and six women deemed it to be the most relevant element. The interviews brought about not the desire to die, but the desire of terminating that painful and suffering condition: I did not want to kill myself, I wanted to get rid of that situation [...] (S6).

People who attempt suicide clearly experience an emotional rollercoaster. It is called ambivalence, or the moment when the urgency toward quitting pain collides with the desire to live. ${ }^{15}$ Hence, individuals who attempt suicide do not wish to terminate their lives, they actually want to eliminate suffering and pain.

As the core group elements are more resistant against changes, they ensure the continuity of the social representation in any context. In this sense, the representation of the women about suicide is strongly grounded on the experiences, values and concepts they built about it. Depression and death, for instance, end up influencing the representation of what the interviewed women think about the suicide. As a consequence, such representation offers us other elements toward comprehending the behaviors of these women.

\section{Intermediary elements}

The higher right quadrant in the four-fold diagram shows words with high frequency, but whose average position in the mention order was not enough to lever them to the core group. Therefore, they constitute the first periphery: hopelessness, fear and exit. In this representation quadrant, hopelessness and fear can be observed as common elements in the depression profile. The term "exit" is related to death and seen as a unique solution: I was horrible, so humiliated [...]. In order to quit that situation, I decided to kill myself [...] (S6).

The lower left quadrant displays words with lower frequencies, yet readily mentioned by the women: relief, regret, pain, family, evil and losses. Due to the low average frequencies, these terms are not found in the core group. As this area contains elements that are not able to alter the core group elements and not even the representation itself, it is then called "contrast zone". ${ }^{16}$ Such representation framework unfolds the elements that integrate both the core group and the peripheral system.

The terms "relief" and "regret" relate to death as an exit, as well as to the ambivalence found in the desire for life and death: after the first attempt, I regretted it, and I was glad for the opportunity of living again [...] (S7).

The terms "family" and "pain" presented the same mention frequencies, totaling 12 times (18\%). The interviews showed a correlation between the suicide and the development of elements located in the depression profile resulting from the hard situations experienced within the family boundaries. This correlation may be observed in the following speech: I feel like a prisoner to everybody. I just can't breathe, they throw everything on my back [...] I think that if I die, everybody will have to sort out their problems [...] (S6).

From cradle to grave, family and friends are essential toward providing us with support and direction, at any time. They are also crucial toward helping us build our perception of the world and in consolidating our individual behavior. By means of the steady interaction among its members, the family, above anything else, should play a relevant role in tackling the ideation, the attempt and the consummation of the suicide. ${ }^{17}$

According to the women, the unbearable feeling of pain rises as an element in the depression profile that makes it very difficult for them to keep living; in other words, these women begin 
to shape the idea of suicide as a potential resource that can culminate with death, a fatal consequence of depression: it is a deep pain, we get so desperate for help, we want to get rid of that situation [...]. I wanted to sleep and do not wake up anymore. I wanted to pass out $[\ldots]$ (S8).

The sedation of conscience is clearly shown in the interviews as a way to get rid of all the suffering, including the terms "evil" and "losses", and appears as a solution to the problems without necessarily substantializing death. The interruption of an endless pain is understood by the suicidal individual as a perfect solution to the problems of life. The expectation of "ceasing that thought" leads to a vulnerable mindset, thus triggering the beginning of the destructive act. ${ }^{18}$

The following aspects can be found among risk factors to depression: living in a dysfunctional family, low social support level, large numbers of stressing events, and limited capacities to cope with the situations. It is worth highlighting that the psychic pain generated by the depression and/or the depression originated from a psychic pain are very hard to determine yet. Depression is capable of leading individuals and those directly or indirectly living with them to suffering and unhappiness, and can be considered as one of the most prevalent disorders of the past and present ${\text { centuries. }{ }^{17}}^{17}$

\section{Peripheral elements}

The lower right quadrant entangles the more mutable representation elements, that is, they vary and clearly reveal the transformations undergone by the representation, thus characterizing the peripheral system: lovelessness, disease, helplessness, liberation, change and rejection. Although all terms are anchored in the social representation related to suicide, the terms "helplessness", "change" and "liberation" are correlated with the violence experienced by the women throughout their lives. On the other hand, the terms "lovelessness", "disease" and "rejection" are correlated with the sickening process, as they represent the violence experience and are manifested through the elements of the depression profile. Being more flexible and showing lower resistance against changes, these elements make individual modulations possible, allowing for flexibility and elasticity in the elaboration of social representations.

The terms "lovelessness" and "rejection" were mentioned by nine women. These elements were also highlighted in the interviews, indicating feelings of rejection and lovenessless that led to a diminished self-esteem and consequently favored the consolidation of the elements of the depression profile.

He looked at me and said that he hated me, that I was disgusting, that he just laid down with me because I compelled him to [...] (S2).

[...] frustration, rejection, humiliation. What a burden, what a pressure. Quite a heavy thing squeezing my chest [...] (S5).

Life experiences filled with feelings of rejection, histories of abuse and losses may act as adverse events and can potentially stimulate the decision for the suicide. ${ }^{19-20}$ Hence, the suicide attempt is comprised of an act-pain process resulting from traumatic situations and experiences. The singularity of this condition must be addressed by a process entangling an embracement and listening culture. ${ }^{21}$

The term "disease" was mentioned by five women and is correlated with another term, "depression", whose mention frequency (22.7\%) was the highest in the core group quadrant. Depression and the occurrence of elements in the depression profile are identified as the major disorders related to the suicide idea and attempt in the interviews, as it can be observed in the following speech: when my mind started getting stirred, I was already depressed. I caught myself crying, I felt different from other people. I felt lower than other people. A deep frustration, a lack of importance [...] a profound anguish [...]. You feel like garbage [...] (S3).

The crying episodes with no apparent reason, the frustration, the lack of importance, and the anguish are characteristics of depression profiles, having their climax in the progressive diminishment of self-esteem. Such framework may evolve to more serious depression profiles associated with a suicidal behavior. The association among psychopathology, ideation, suicide attempt and suicide has been broadly discussed, having depression as the most frequent diagnosis. ${ }^{22-23}$ Such correlation may be clearly illustrated in the following statement: It all began with depression. I just wanted to leave and vanish. If I could, I would lock myself in the bedroom and not do a thing anymore [...] In order not to live like that anymore, I decided to kill myself [...] (S6).

The term "helplessness" was mentioned by four women, being considered by $50 \%$ of them as the second most important element in the representation of the peripheral system. In the thematic 
analysis interviews, the feeling of helplessness is frequently revealed by women undergoing violence, whenever they are not able to find a way out of a tense relationship with their mates.

It's very hard for us to speak about it, to press charges against them [...] They look like artists playing the monsters and the good guys at the same time. He harassed me [...] I did not have anyone to count on (S3).

I allowed that to happen because I just could not leave that situation [...] I was totally paralyzed by cowardice and absorbed everything he said to me [...] I stored each gesture, each word, and started dying little by little [...] (S7).

The domestic violence repeatedly and cruelly manifested in the daily lives of some women in quite a natural way is responsible for the fear, shame and isolation, thus detaching the woman from the social support networks and contributing to the invisibility of her grievances. ${ }^{24}$

The process of pressing charges against suffered violence can be as difficult and complex for the woman as the prevention process itself. The major reasons that complicate this process are the fear of extreme acts of violence on the part of the mate and the shame for the failure of the marriage with the loved person. It must also be highlighted that the difficulty these women have to interrupt violent relationships is grounded on their affection, their financial dependence, and their parenthood relationship. ${ }^{25}$

The terms "liberation" and "change" were mentioned by four and three women, respectively. The interviews showed the understanding of the need of getting out, changing and/or getting rid of the suffering and psychic pain. The liberation, founded on self-recognition, rises as a necessary element toward change and can be gradually reached by means of psychological and psychiatric support.

Therapy has been very important. It made me see a possibility of being happy again, in spite of the fear and the memories (S7).

Nowadays, I love myself a bit more, I'm special, I don't want to suffer anymore (S3).

I got much better after therapy, as I was able to talk about things that I had always kept to myself. Now, I feel free (S6).

These testimonies signal the relevance of psychotherapy care that addresses a different look at the women who experienced violence and attempted suicide. These women can be aided toward identifying other exit doors from their problems in life. The care process demands the appreciation of the intersubjectivity in the healthcare practice. $^{26}$

\section{FINAL CONSIDERATIONS}

The social representation of women undergoing domestic violence and suicide attempt about the term "suicide" is anchored in life stories permeated by rejection and lovelessness that lead these women to diseases and, above all, depression. Feeling powerless to cope with the change and the liberation, they choose to die, allowing us to apprehend that the histories of violence experienced by these women in several moments of their family and marriage lives unleash emotional dilemmas that reach an apex when they decide to interrupt life.

The present research points to the correlation between domestic violence and suicide. On the other hand, the study was limited by the particularities of the subjects. As their social representations are specifically related to this group, the development of scientific studies directed to the comprehension of the elements associated with the choice for suicide would be a necessary step.

The findings certainly contribute toward providing elements to the identification of the complexity and multicausality of phenomena such as the suicide and the suicide attempt, and offer subsidies to action plans that can guide the healthcare practices. This fact should lead us to propose caregiving processes that prioritize the others in their physical, biological and psychosocial dimensions, thus allowing for the acknowledgement of their family contexts and the design of caregiving processes personalized to the specificities that permeate their life histories and current demands.

In this perspective, nursing practice spaces must be valued for the implementation of healthcare and education actions that enable the promotion of caregiving processes based on the subject-subject relationship and which devise the singularities of the woman within the context of experiencing violence and suicide attempt, thus favoring the perception of the subjectivities in the daily activities of the healthcare practices.

\section{REFERENCES}

1. Ministério da Saúde (BR) [pagina na internet]. Indicadores e dados básicos. Óbitos por causas externas - suicídios - séries estatísticas. Brasília (DF): MS; 2010. [acesso 2012 Out 08]. Disponível 
em: seriesestatisticas.ibge.gov.br/series. aspx?vcodigo $=$ MS11

2. Rigo S. Suicídio. In: Anais do Seminário Estadual sobre Violência e Saúde. Salvador (BA): SESAB; 2009.

3. Durkheim E. O suicídio. São Paulo (SP): Martin Claret; 2005.

4. Prieto DYC. Indicadores de proteção e de risco para suicídio por meio de escalas de auto-relato [tese]. Brasília (DF): Universidade de Brasília. Instituto de Psicologia; 2007.

5. Soares BM. Mulheres invisíveis: violência conjugal e novas políticas de segurança. Rio de Janeiro (RJ): Civilização Brasileira; 1999.

6. Marcondes Filho W, Mezzaroba L, Turini CA, Koike A, Motomatsu Filho A, Shibayama EEM, et al. Tentativas de suicídio por substâncias químicas na adolescência e juventude. Adolesc Latino-Am [online]. 2002 [Acesso 2009 Set 8]. Disponível em: http:/ / raladolec.bvs.br/scielo.php? script $=$ sci arttext\&pid=S141471302002000200007\&lng= es\&nrm=iso

7. Abric JC. Abordagem estrutural das representações sociais. Psicol Esc Educ. 1971 Jul-Set; 3(1):311-26.

8. Abric JC. A abordagem estrutural das representações sociais: desenvolvimentos recentes. In: Campos PHF, Loureiro MCS, organizadores. Representações sociais e práticas educativas. Goiânia (GO): ed. UCG; 2003.

9. Sá CP. Núcleo central das representações sociais. Petrópolis (RJ): Vozes; 1996.

10. Triviños ANS. Introdução à pesquisa em ciências sociais. São Paulo (SP): Atlas; 2006.

11. Verges P. Approche du noyau central: proprietés quantitatives et estructurales. In: Guimelli C, organisateur. Structures et transformation des representations sociales. Paris (FR): Delachaux et Niestlé; 1994. p. 233-53.

12. Oliveira DC, Marques SC, Gomes AMT, Teixeira MCTV. Análise das evocações livres: uma técnica de análise estrutural das representações sociais. In: Moreira ASP, Camargo BV, Jesuíno JC, Nóbrega SM, organizadores. Perspectivas teórico-metodológicas em representações sociais. João Pessoa (PB): Editora UFPB; 2005. p.573-603.

13. Abric JC. A organização das representações sociais: sistema central e sistema periférico. In: Guimelli $\mathrm{CH}$. Structures et transformations des représentations sociales. Lausanne (CH): Delachaux et Niestlé; 1994. p. 73-84.
14. Organização Mundial da Saúde (OMS). Relatório sobre saúde no mundo. Saúde mental: nova concepção, nova esperança. Genebra $(\mathrm{CH})$ : OMS; 2001.

15. Organização Mundial da Saúde (OMS). Relatório mundial sobre violência e saúde. Brasília (DF): OMS; 2002.

16. Oliveira CC, Maugin C, Oliveira ECF, Melo FDP, Silva FCA, Dias FEJ, et al. A dor e o controle do sofrimento (II). Rev Psicofisiologia [online]. 2005 [acesso 2010 Out 20]; Disponível em: http:/ /www. psicologia.com.pt/artigos/ver_artigo_licenciatura. php? codigo $=$ TL0021\&area $=\mathrm{d} 2$

17. Baptista MN. Suicídio e depressão (atualizações). Rio de Janeiro (RJ): Guanabara Koogan; 2004.

18. Wang YP, Ramadam ZBA. Aspectos psicológicos do suicídio. In: Meleiro AMAS, Teng CT, Wang YP, organizadores. Suicídio: estudos fundamentais. São Paulo (SP): Segmento Farma; 2004.

19. Prieto D, Tavares, M. Fatores de risco para suicídio: incidência, eventos estressores e transtornos mentais. J Bras Psiquiatr. 2005 Abr-Jun; 54(2):146-54.

20. Cankaya B, Talbot NL, Ward EA, Duberstein PR. Parental sexual abuse and suicidal behaviour among women with major depressive disorder. Can J Psychiatry [online]. 2012 Jan [acesso 2013 Mai 22]; 57(1):45-51. Disponível em: www.ncbi.nlm.nih.gov/ pubmed/22296967

21. Macedo MMK, Werlang BSG. Trauma, dor e ato: o olhar da psicanálise sobre uma tentativa de suicídio. Ágora. 2007 Jan-Jun; 10(1):86-106.

22. Chachamovich E, Stefanello S, Botega N, Turecki G. Quais são os recentes achados clínicos sobre a associação entre depressão e suicídio? Rev Bras Psiquiatria. 2009 Mai; 31(1):18-25.

23. Louise B, Mats B. Repetition of suicide attempts across episodes of severe depression Behavioural sensitisation found in suicide group but not in control. BMC Psychiatry [online] 2011 [acesso 2013 Mai 22]; 11(5):2-7. Disponível em: http://www. biomedcentral.com/1471-244X/11/5

24. Monteiro CFS, SOUZA IEO. Vivência de violência conjugal: fatos do cotidiano. Texto Contexto Enferm. 2007 Jan-Mar; 16(1):26-31.

25. Soares MB. Enfrentando a violência contra a mulher. Brasília (DF): Secretaria Especial de Políticas para as Mulheres; 2005.

26. Ayres JRCM. Sujeito, intersubjetividade e práticas de saúde. Ciênc Saúde Coletiva. 2001; 6(1):63-72. 